\title{
Molecular detection of Ehrlichia canis and Anaplasma platys in dogs from municipality of Belém, State of Pará, Brazil
}

\section{Verucia Maria Dias Brandão ${ }^{1}$ Pedro Henrique Marques Barrozo ${ }^{1}$ (D) Luciane Oeiras Sousa ${ }^{1}$ (i) Rafaelle Cunha dos Santos ${ }^{1}$ Katiane Schwanke ${ }^{1}$ Francisco Dantas Sampaio Junior ${ }^{1}$ Welton Seabra Prado ${ }^{1}$ Alessandra Scofield Amaral ${ }^{1}$ Gustavo Góes Cavalcante ${ }^{* *}$ iD}

'Laboratório de Parasitologia Animal, Universidade Federal do Pará (UFPA), 68740970, Castanhal, Pará, Brasil. E-mail: ggcavalcante@ufpa.br. *Corresponding author.

ABSTRACT: The occurrence of diseases transmitted by ticks in dogs is very frequent in Brazil, among these diseases we can highlight the ehrlichiosis and anaplasmosis, which are caused by Ehrlichia canis and Anaplasma platys, respectively. The objective of this study was to survey the occurrence of these pathogens in blood samples from domiciled and stray dogs from the city of Belém, Pará. Two hundred and seventy six dogs were sampled for convenience, and the DNA extracted from the blood of these animals was submitted to nested-PCR for research of E. canis and A. platys. E. canis DNA was detected in 39.4\% (109/276) and A. platys DNA in $23.1 \%$ (64/276) of the samples, there was a statistically significant difference between the frequency of these agents $(P<0.0001)$, and there was coinfection in 13.4\% (37/276) of animals. The frequency of detection of these parasites was higher in stray dogs than in those domiciled for both E. canis (OR=2.84) and A. platys $(O R=10.5)$. Considering the results, it was possible to conclude that E. canis and A. platys are present in the studied population, with stray dogs being more affected by these parasites.

Key words: Canine monocytic ehrlichiosis, Canine cyclic thrombocytopenia, hemoparasites, Anaplasmatecea, Pará.

Deteç̧ão molecular de Ehrlichia canis e Anaplasma platys em cães do município de Belém, Estado do Pará, Brasil

RESUMO: A ocorrência de doenças transmitidas por carrapatos em cães é muito frequente no Brasil, dentre estas enfermidades podemos destacar a erliquiose e a anaplasmose, que são causadas por Ehrlichia canis e Anaplasma platys, respectivamente. O objetivo deste trabalho foi fazer um levantamento da ocorrência destes patógenos em amostras de sangue de cães domiciliados e errantes do município de Belém, Pará. Foram amostrados 276 cães por conveniência, sendo que o DNA extraído do sangue desses animais foi submetido à nested-PCR para a pesquisa de E. canis e A. platys. O DNA de E. canis foi detectado em 39,4\% (109/276), e o DNA de A. platys em 23,1\% (64/276) dos cães amostrados. Houve diferença estatisticamente significante entre a frequência desses agentes ( $<<0,0001)$, pois foi encontrada coinfecção entre os agentes em 13,4\% (37/276) dos animais. A frequência de detecção desses parasitos foi maior em cães errantes do que nos domiciliados tanto para E. canis $(O R=2,84)$ quanto para A. platys $(O R=10,5)$. Diante dos resultados, foi possível concluir que E. canis e A. platys estão presentes na população canina estudada, sendo os cães errantes mais acometidos por esses parasitos.

Palavras-chave: Erliquiose monocítica canina, Trombocitopenia cíclica canina, hemoparasites, Anaplasmatecea, Pará.

\section{INTRODUCTION}

Canine diseases exhibiting high morbidity and mortality that are caused by agents transmitted by ticks form a significant proportion of the cases seen in veterinary clinics. These diseases included canine monocytic ehrlichiosis (CME) and canine cyclic thrombocytopenia (CCT), that are caused by etiological agents Ehrlichia canis and Anaplasma platys, respectively (PAULINO et al., 2018; MACCHI et al., 2019).
In Brazil, the tick Rhipicephalus sanguineus is the main carrier of these pathogens and is abundant in large parts of the national territory. In addition to these pathogens, the tick can also transmit other pathogenic microorganisms such as Babesia spp. and Hepatozoon canis that cause common mixed infections (CICUTTIN et al., 2015; HAPPI et al., 2018).

Both CME and CCT are characterized by fever, weight loss, anorexia, and apathy, which are usually more evident in cases of co-infections (BOUZOURAA, 2016; LIMA et al, 2019). Since 
the clinical signs of these infections are not specific, laboratory support is required in order to establish a confirmatory diagnosis. Studies have shown that molecular diagnostic techniques have high sensitivity and specificity for these infections (LAUZI et al., 2016; AZHAHIANAMBI et al., 2018; VLAHAKIS et al., 2018).

The importance of these diseases has been highlighted by the small number of epidemiological studies that have already been carried out in the northern region of Brazil using molecular biology tools (RIBEIRO et al., 2017; SOARES et al., 2017; VIEIRA et al., 2018; PAULINO et al., 2018). Thus, the objective of our study was to determine the rates of incidence of these pathogens in domesticated and stray dogs in the municipality of Belém, Pará, Brazil.

\section{MATERIALS AND METHODS}

\section{Study area}

The study was conducted in the municipality of Belém $\left(01^{\circ} 23.6^{\prime \prime} \mathrm{S}\right.$ and $\left.048^{\circ} 29^{\prime} .5^{\prime \prime} \mathrm{W}\right)$ (capital of the state of Pará), which has approximately 1,485,732 inhabitants (IBGE, 2018). The climate in Belém is hot and humid throughout the year and the average temperature is $30{ }^{\circ} \mathrm{C}$ with a relative humidity of around $78 \%$ (INPE, 2019).

\section{Sampling}

Blood samples were collected from 276 adult dogs that were then divided into two groups. Group A consisted of 146 stray dogs that were captured by the Center for Zoonoses Control (CCZ), while group $\mathrm{B}$ consisted of 130 pet dogs that belonged to four neighborhoods and were selected during an anti-rabies vaccination campaign.

Samples were collected by puncturing the cephalic vein using $5 \mathrm{~mL}$ syringes and sterile needles $(25 \times 7 \mathrm{~mm})$. The samples were subsequently stored in vacuum tubes containing EDTA and frozen at -20 ${ }^{\circ} \mathrm{C}$ until DNA extraction.

\section{Polymerase chain reaction (PCR)}

DNA extraction from whole blood samples was performed using the commercial kit Illustra $^{\circledR}$ Blood Genomic Prep Mini Spin Kit (GE Healthcare), in accordance with the manufacturer's protocol. A total of $300 \mu \mathrm{L}$ of blood was used in each extraction. The DNA obtained was analyzed using spectrophotometry by the Picodrop microliter ${ }^{\mathbb{B}}$ (Picodrop Limited).

A nested PCR was performed for the detection of E. canis DNA using the primers ECC
(5'-AGAACGAACGCTGGCGGCAAGCC-3') and ECB (5'-CGTATTACCGCGGCTGCTGGC-3'). These primers amplified the 478 base pairs (bp) fragment in the first reaction. In the second reaction, we used the primers $\mathrm{HE}$ (5'TATAGGTACCGTCATTATCTTCCCTAT-3') andECA (5'-CAATTATTTATAGCCTCTGGCTATAGGAA-3') in order to amplify the final product containing $389 \mathrm{bp}$.

The amplification solution that was used for the amplification of $E$. canis was composed of buffer (100 mM Tris-HCl, $\mathrm{pH}=8.5,500 \mathrm{mM} \mathrm{KCl})$, $50 \mathrm{mM} \mathrm{MgCl}_{2}, 2 \mathrm{U}$ of Taq DNA polymerase (Ludwig Biotec $^{\circledR}$ ), $0.2 \mathrm{mM}$ of each dNTP, and 11 pmol of each of the primers. In the first reaction, $5 \mu \mathrm{L}$ of test DNA $(\sim 100 \mathrm{ng})$ was used and in the second reaction, we used $1 \mu \mathrm{L}$ of the product of the first reaction, yielding a final volume of $25 \mu \mathrm{L}$. This reaction amplifies only part of the E. canis 16S rRNA gene.

The reactions were performed using a Veriti 96 Well Thermal Cycler (Applied Biosystems ${ }^{\circledR}$ ). In order to detect the DNA of E. canis, the first reaction that we carried out was an amplification protocol with an initial denaturation step that was performed for three minutes at $94{ }^{\circ} \mathrm{C}$. This was followed by 35 cycles for one minute at $94{ }^{\circ} \mathrm{C}, 30$ seconds at $60{ }^{\circ} \mathrm{C}$ and 40 seconds at $72{ }^{\circ} \mathrm{C}$. A final extension step was performed for three minutes at $72{ }^{\circ} \mathrm{C}$. For the second reaction, the initial denaturation step was carried out for one minute at $94{ }^{\circ} \mathrm{C}$. This was followed by 35 cycles for one minute at $94{ }^{\circ} \mathrm{C}, 30$ seconds at $62{ }^{\circ} \mathrm{C}$ and 40 seconds for $72{ }^{\circ} \mathrm{C}$. Subsequently, the final extension was performed for 3 minutes at $72^{\circ} \mathrm{C}$.

For the detection of the DNA of $A$. platys we used the primers $8 \mathrm{~F}$ (5' AGTTTGATCATGGCTCAG-3') and 1448R ( 5 '-CCATGGCGTGACGGGCAGTGT-3') in the first reaction, while in the second reaction the primers used were APLATYS (5'GATTTTTGTCGTAGCTTGCTATG-3') and EHR16SR (5'-TAGCACTCATCGTTTACAGC-3'). The primers in the second reaction amplified the final product of the 16S rRNA gene containing $678 \mathrm{bp}$.

The amplification solution used in the reaction was composed of the buffer $(100 \mathrm{mM}$ Tris$\mathrm{HCl}, \mathrm{pH}=8.5,500 \mathrm{mM} \mathrm{KCl}), 50 \mathrm{mM} \mathrm{MgCl}, 2.5$ units of Taq DNA polymerase (Ludwig Biotec ${ }^{\circledR}$ ), 3 $\mathrm{mM}$ of each dNTP (dATP, dGTP, dCTP, and dTTP), and 11 pmol of each primer. In the first reaction, 5 $\mu \mathrm{L}$ of the test DNA $(\sim 100 \eta \mathrm{g})$ was used and in the second reaction, we used $1 \mu \mathrm{L}$ of the product of the first reaction, to obtain a final volume of $25 \mu \mathrm{L}$. This reaction amplified only part of the $16 \mathrm{~S}$ rRNA gene of $A$. platys. 
The temperature protocol of the first reaction for detection of the DNA of $A$. platys was as follows: an initial denaturation step that was performed at $94{ }^{\circ} \mathrm{C}$ for 7 minutes, followed by 40 cycles at $94{ }^{\circ} \mathrm{C}$ for 1 minute, at $48{ }^{\circ} \mathrm{C}$ for 1 minute and at $72{ }^{\circ} \mathrm{C}$ for 40 seconds. The final extension step was performed at 72 ${ }^{\circ} \mathrm{C}$ for 10 minutes. For the second reaction the initial denaturation was performed at $94{ }^{\circ} \mathrm{C}$ for 5 minutes, followed by 40 cycles at $94{ }^{\circ} \mathrm{C}$ for 1 minute, at $56^{\circ} \mathrm{C}$ for 30 seconds and at $72{ }^{\circ} \mathrm{C}$ for 30 seconds, and the final extension step was performed at $72{ }^{\circ} \mathrm{C}$ for 7 minutes.

The blood from a dog with parasitemia that was detected during blood smear examination using optic microscopy and was "positive" in the nested PCR was used as a positive control for E. canis. The positive control for A. platys was a blood sample obtained from a dog. The sample was "positive" in nested PCR with sequencing, thus confirming the presence of $A$. platys. The sample was provided by Professor Dr. Evonnildo Costa Gonçalves and DNA was extracted from the whole blood of a parasitologically negative and asymptomatic dog. This sample, which had no alterations in blood count and was "negative" in the nested PCR, was used as a negative control. In order to avoid false positives, a contamination control was used in all the reactions. The contamination control was an amplification solution and double-distilled water without DNA.

The amplified products were analyzed by horizontal electrophoresis in $1.5 \%$ agarose gel stained with ethidium bromide $(0.5 \mu \mathrm{g} / \mathrm{mL})$. The length of the amplified products was estimated using a 100 base pair standard (100 bp ladder-Ludwig Biotec) in each gel. Visualization of the amplified products was performed using a photo documentation system and a UV transilluminator (Quantum ST41000/26M).

\section{Statistical analysis}

Evaluation of the number of positive samples in the nested PCR and the comparative analysis between the numbers of samples positive for both agents based on the sample group, were performed using the Chi-square test (significance level of 5\%) and the BioEstat ${ }^{\circledR}$ v.5.3 program.

The Odds Ratio (OR) was applied in order to evaluate the effect of the characteristics of each sample group in relation to the presence of $E$. canis and $A$. platys DNA (MEDRONHO, 2006).

\section{RESULTS}

DNA of at least one of the agents studied was detected in $49.2 \%(136 / 276)$ of the dogs sampled. The frequency of detection of the E. canis and A. platys DNA was 39.4\% (109/276) and 23.1\% (64/276), respectively $(\mathrm{P}=0.0001)$. Simple infection by $E$. canis and $A$. platys was observed in $26.0 \%(72 / 276)$ and $9.7 \%$ (27/276) of dogs, respectively, while mixed infection was detected in $13.4 \%(37 / 276)$ of animals. There was no statistically significant difference in the occurrence of E. canis and A. platys $(\mathrm{P}<0.0001)$ between the sample groups. Distribution of positive samples based on the etiological agents and sample groups is presented in table 1 .

The analysis of the OR showed that the likelihood of detection of $E$. canis and A. platys DNA in animals belonging to group A (stray dogs) was 2.84, which was 10.5 times greater than the likelihood of their detection in group B (pet dogs).

\section{DISCUSSION}

Epidemiological studies on the etiologic agents of CME and CCT have already been carried out in several regions of Brazil (LEAL et al., 2015; MAKINO et al., 2016; SOARES et al., 2017; VIEIRA et al., 2018; LOPES et al., 2019). However, there are few studies on the molecular epidemiology of these agents in the northern region of the country.

Table 1 - Distribution of positive samples for Ehrlichia canis and Anaplasma platys from stray dogs (A) and pet dogs (B) from the municipality of Belém.

\begin{tabular}{lccc}
\hline Agent & & & \\
& & & \\
& A & T & \\
E. canis & $32.1 \%(47 / 146)^{\mathrm{a}}$ & $19.2 \%(25 / 130)^{\mathrm{b}}$ & $26.0 \%(72 / 276)$ \\
A. platys & $15.7 \%(23 / 146)^{\mathrm{c}}$ & $3.1 \%(4 / 130)^{\mathrm{d}}$ & $9.7 \%(27 / 276)$ \\
E. canis e A. platys & $24.6 \%(36 / 146)^{\mathrm{e}}$ & $0.7 \%(1 / 130)^{\mathrm{f}}$ & $13.4 \%(37 / 276)$ \\
Total & $72.6 \%(106 / 146)^{\mathrm{g}}$ & $23.1 \%(30 / 130)^{\mathrm{h}}$ & $49.2 \%(136 / 276)$ \\
\end{tabular}

${ }^{*}$ Different letters on the same line indicate statistical difference $(\mathrm{P}<0,05)$. 
RUFINO et al. (2013) conducted the first molecular diagnosis of infection by $E$. canis and A. platys in the State of Pará using multiplex PCR. However, they subjected only 30 animals to this test.

In the present study, nested PCR was performed with the aim of obtaining high accuracy. Nested PCR can also be considered a confirmatory test for these infections, because it has higher sensitivity than other routine techniques, such as the blood smear (DONI et al., 2016; HAN et al., 2017) and conventional PCR (YANG et al., 2017).

Nested PCR revealed that $49.2 \%$ of the dogs examined were infected by at least one of the etiological agents being studied, indicating a high frequency of infected dogs in the region. It is worth mentioning that the municipality of Belém is located within the area of prevalence of the tropical lineage of $R$. sanguineus, which has already been demonstrated the ability to transmit E. canis to dogs, this explains the movement of this agent between dogs in the region (MORAES-FILHO et al., 2015).

In similar studies performed in different Brazilian states, rates of infection by E. canis in dogs ranged between $3 \%$ and $76 \%$. VIEIRA et al. (2018) detected an infection rate of $7.4 \%$ in pet dogs that were seen at a veterinary hospital and a castration campaign at the School of Veterinary Medicine in the state of Espírito Santo. PAULINO et al. (2018) reported an infection rate of $24.8 \%$ in dogs from rural and urban areas in the state of Rio de Janeiro. ROTONDANO et al. (2017) detected E. canis in $8.9 \%$ of pet dogs in the urban area of the state of Paraíba. MAKINO et al. (2016) reported an infection rate of $76.3 \%$ in pet dogs in the state of Mato Grosso. In all the studies mentioned above, as well as in our present study, molecular diagnostics were performed in animals without clinical suspicion of CME, indicating that a highly sensitive technique can reveal cryptic cases of infection by this agent.

DAGNONE et al. (2003) reported the first molecular diagnosis of infection by $E$. canis in Brazil, they related an infection rate of $21 \%$. Several other authors also reported infection by $E$. canis. For example, WITTER et al. (2013) reported an infection rate of $23.3 \%$ in Cuiabá-MT, AGUIAR et al. (2013) reported $65 \%$ infection rate in several regions of Brazil and SOARES et al. (2017) reported an infection rate of $59.66 \%$ in Campo Grande-MS. The dogs in these studies were presented in veterinary hospitals with clinical or serologic signs of infection. This was in different from our present study in which the selection of dogs was entirely random. However, consistent with the observations in other regions, we also reported that the number of infected animals was above $20 \%$, thus implying the movement of the parasite in dogs in the region.

The number of samples in which $A$. platys DNA was detected was lower than that reported by RAMOS et al. (2009) in Pernambuco and by RAMOS et al. (2010) in Recife. The rates of infection reported were $55 \%$ and $48.78 \%$, respectively, in dogs with some clinical signs that were suggestive of the disease. These dogs were also being treated in Veterinary Hospitals. This may have happened because the sample group in our study was not composed of animals that presented in clinics and hospitals; rather, the group was composed of animals that did not show any clinical signs of the disease.

We reported a higher rate of infection compared to the rates of infection reported in other studies that were carried out in animals that had no clinical signs suggestive of infection by $A$. platys. RIBEIRO et al. (2017) reported an infection rate of $32.9 \%$ in stray dogs in the state of Paraná. LASTA et al. (2013) observed infection in $14.07 \%$ of stray dogs in the state of Rio Grande do Sul. VIEIRA et al. (2018) detected an infection rate of $6.34 \%$ in pet dogs in the state of Espírito Santo.

One common factor that has been observed in different studies is coinfection even in animals without clinical evidence of infection (LAUZI et al. 2016). In the present study, such animals accounted for $13.4 \%(37 / 276)$ of the sample. RAMOS et al. (2010) and SOARES et al. (2017) reported a similar result using nested PCR and detected coinfection in $16 \%$ and $9.94 \%$ of dogs, respectively. Conversely, SILVA et al. (2012) and VIEIRA et al. (2018) detected a coinfection rate of $5.47 \%$ and $3.70 \%$, respectively, using conventional PCR. Given the difficulty of detecting multiple infections, the use of more sensitive techniques such as nested PCR, can facilitate the detection of co-infected animals.

Other than the similarity between the geographical areas of occurrence, the fact that a significant number of animals were co-infected implies that $R$. sanguineus is probably capable of transmitting both agents. Studies that aimed to detect the DNA of $E$. canis and $A$. platys in both dogs and in ticks that infest these animals, reinforce the involvement of this tick in the transmission cycle of these agents (CICUTTIN et al., 2015; SILVA et al., 2016).

The comparative analysis between the rates of infection by $E$. canis and $A$. platys between the sample groups indicated that the errant behaviors or the management of the animals in the $\mathrm{CCZ}$ are risk factors for this infection. This may be due to greater 
exposure of stray animals to tick infestation by the vector $R$. sanguineus, compared to pet animals. Pet animals also received more intense care, such as periodic examinations and correct treatment for possible diseases, in order to prevent infection by ectoparasites (LABRUNA et al., 2001; LIU et al., 2016; FIGUEIREDO et al., 2017).

\section{CONCLUSION}

We concluded that the agents assessed are present in high frequency in the region studied. Stray dogs are at a greater risk of infection compared to pet dogs.

\section{ACKNOWLEDGEMENTS}

This study was funded by the Brazilian Federal Agency for Support and Evaluation of Graduate Education (CAPES - Finance code 001) and Federal University of Pará.

\section{BIOETHICS AND BIOSSECURITY COMMITTEE APPROVAL}

This study was submitted for analysis by the Research Ethics Committee of experimental animals of the Federal University of Pará - CEPAE / UFPA - Protocol 083-12.

\section{DECLARATION OF CONFLICT OF INTERESTS}

The authors declare that they have no conflict of interest. The founding sponsors had no role in the design of the study, nor in the data collection, analyses, or interpretation of data, the writing of the manuscript, nor the decision to publish the results.

\section{AUTHORS' CONTRIBUTIONS}

The authors contributed equally to the manuscript.

\section{REFERENCES}

AGUIAR, D. M. et al. Genetic diversity of Ehrlichia canis in Brazil Veterinary Microbiology, v.164, n.3-4, p.315-321, Jun. 2013. Available from: <https://doi.org/10.1016/j.vetmic.2013.02.015>. Accessed: Mar. 25, 2019. doi: 10.1016/j.vetmic.2013.02.015.

AZHAHIANAMBI, P. et al. Evaluation of multiplex PCR assay for detection of Babesia spp, Ehrlichia canis and Trypanosoma evansi in dogs. Acta Tropica, v.188, p.58-67, Dec. 2018. Available from $<$ https://doi.org/10.1016/j.actatropica.2018.08.028>. Accessed: Mar. 05, 2019. doi: 10.1016/j.actatropica.2018.08.028

BOUZOURAA, T. et al. Clinical and laboratory features of canine Anaplasma platys infection in 32 naturally infected dogs in the Mediterranean basin Tarek. Ticks and Tick-borne Diseases, v.7, n. 6, p.1256-1264, Oct. 2016. Available from: <https://doi org/10.1016/j.ttbdis.2016.07.004>. Accessed: May, 24, 2019. doi: 10.1016/j.ttbdis.2016.07.004
CICUTTIN, L. G. et al. Infection with Ehrlichia canis and Anaplasma platys (Rickettsiales: Anaplasmataceae) in two lineages of Rhipicephalus sanguineus sensu lato (Acari: Ixodidae) from Argentina. Ticks and Tick-borne Diseases, v.6, n.6, p.724729, Sep. 2015. Available from: <https://doi.org/10.1016/j. ttbdis.2015.06.006>. Accessed: Jan. 30, 2019. doi: 10.1016/j. ttbdis.2015.06.006

DAGNONE, A. S. et al. Ehrlichiosis in anemic, thrombocytopenic, or tick-infested dogs from a Hospital population in South Brazil. Veterinary Parasitology, v.117, n.4, p.285-290, Nov. 2003. Available from: <https://doi.org/10.1016/j.vetpar.2003.10.001>. Accessed: Dec. 20, 2018. doi: 10.1016/j.vetpar.2003.10.001.

DONI, Y. N. et al. Detection of Plasmodium using filter paper and nested PCR for patients with malaria in Sanliurfa, in Turkey. Malaria Journal, v.15, p.290-299, May. 2016. Available from: $<$ https://doi.org/10.1186/s12936-016-1334-2>. Accessed: May, 30, 2019. doi: 10.1186/s12936-016-1334-2.

FIGUEIREDO, A. L. et al. Exposure to vector-borne pathogens in privately owned dogs living in different socioeconomic settings in Brazil. Veterinary Parasitology, v.243, p.18-23, Aug. 2017. Available from: <https://doi.org/10.1016/j.vetpar.2017.05.020>. Accessed: Dec. 12, 2018. doi: 10.1016/j.vetpar.2017.05.020.

HAN, Z. T. et al. Comparison of microscopy and PCR for the detection of human Plasmodium species and Plasmodium knowlesi in southern Myanmar. Asian Pacific Journal of Tropical Biomedicine, v.7, n.8, p.680-685, Aug. 2017. Available from: $<$ https://doi.org/10.1016/j.apjtb.2017.06.004>. Accessed: May, 29, 2019. doi: 10.1016/j.apjtb.2017.06.004.

HAPPI, N. A. et al. Detection and identification of blood-borne infections in dogs in Nigeria using light microscopy and the polymerase chain reaction. Veterinary Parasitology: Regional Studies and Reports, v.11, p.55-60, Jan. 2018. Available from: <https://doi.org/10.1016/j.vprsr.2017.12.002>. Accessed: May, 13, 2019. doi: 10.1016/j.vprsr.2017.12.002.

IBGE. Instituto Brasileiro de Geografia e Estatística, 2018. Available from: <https://www.ibge.gov.br/cidades-e-estados/pa/ belem.html>. Accessed: May, 13, 2019.

INPE. Instituto Nacional de Pesquisas Espaciais, 2019. Available from: <http://www.cptec.inpe.br/cidades/tempo/221>. Accessed: May, 13, 2019.

LABRUNA, M. B.; PEREIRA, M. C. Carrapato em cães no Brasil. Clínica Veterinária, São Paulo: Guara, 2001. v.6, p.24-32.

LASTA, S. C. Molecular detection of Ehrlichia canis and Anaplasma platys in dogs in Southern Brazil. Revista Brasileira de Parasitologia Veterinária, v.22, n.3, p.360-366, Sep. 2013. Available from: <http:// dx.doi.org/10.1590/S1984-29612013000300007>. Accessed: Dec. 11, 2018. doi: 10.1590/S1984-29612013000300007.

LAUZI, S. et al. Molecular detection of Anaplasma platys, Ehrlichia canis, Hepatozoon canis and Rickettsia monacensis in dogs from Maio Island of Cape Verde archipelago. Ticks and Tick-borne Diseases, v.7, n.5, p.964-969, Jul. 2016. Available from: <https://doi.org/10.1016/j.ttbdis.2016.05.001>. Accessed: May, 22, 2019. doi: 10.1016/j.ttbdis.2016.05.001.

LEAL, A. S. D. P. et al. Infecção por hematozoários nos cães domésticos atendidos em serviço de saúde animal, Rio de Janeiro, 
Brasil. Revista Brasileira de Medicina Veterinária, v.37, (Supl.1), p.55-62, Dec. 2015. Available from: <http://rbmv.org/ index.php/BJVM/article/view/478>. Accessed: Mar. 16, 2019.

LIMA, F. C. M. et al. Conventional and Holter Electrocardiographic Assessment of Dogs Infected Naturally With Acute Canine Monocytic Ehrlichiosis. Topics in Companion Animal Medicine, v.35, p.31-37, Jun. 2019. Available from: $<$ https://doi. org/10.1053/j.tcam.2019.03.005>. Accessed: Jan. 11, 2019. doi: 10.1053/j.tcam.2019.03.005.

LIU, M. et al. Molecular survey of canine vector-borne diseases in stray dogs in Thailand. Parasitology International, v.65, n.4, p.357-361, Aug. 2016. Available from: <https://doi.org/10.1016/j. parint.2016.04.011>. Accessed: Aug. 19, 2018. doi: 10.1016/j. parint.2016.04.011.

LOPES, G. M. et al. Occurrence of Ehrlichia canis and Hepatozoon canis and probable exposure to Rickettsia amblyommatis in dogs and cats in Natal, RN. Brazilian Journal of Veterinary Parasitology, v.28, n.1, p.151-156, Jan-Mar. 2019. Available from: $<$ http://dx.doi.org/10.1590/s1984-296120180065>. Accessed: Feb. 20, 2019. doi: 10.1590/s1984-296120180065.

ROTONDANO, F. E. T. et al. Ehrlichia canis and Rickettsia spp. in dogs from urban areas in Paraiba state, northeastern Brazil. Brazilian Journal of Veterinary Parasitology, v.26, n.2, p.211215, Apr.-Jun. 2017. Available from: <http://dx.doi.org/10.1590/ s1984-29612017030>. Accessed: Feb. 23, 2019. doi: 10.1590/ s1984-29612017030.

MACCHI. P. S. et al. Prevalence, molecular characterization and risk factor analysis of Ehrlichia canis and Anaplasma platys in domestic dogs from Paraguay. Comparative Immunology, Microbiology and Infectious Diseases, v.62, p.31-39, Feb. 2019. Available from: <https://doi.org/10.1016/j.cimid.2018.11.015>. Accessed: May, 23, 2018. doi: 10.1016/j.cimid.2018.11.015.

MAKINO, H. et al. Ehrlichia canis detection in dogs from Várzea Grande: a comparative analysis of blood and bone marrow samples. Ciência Rural, v.46, n.2, p.310-314, feb. 2016. Available from: $<$ http://dx.doi.org/10.1590/0103-8478cr20150090>. Accessed: May, 15, 2019. doi: 10.1590/0103-8478cr20150090.

MEDRONHO, R.A. et al. Epidemiologia. São Paulo: Ed. Atheneu, 2006. p.493.

MORAES-FILHO J. et al. Comparative Evaluation of the Vector Competence of Four South American Populations of the Rhipicephalus sanguineus Group for the Bacterium Ehrlichia canis, the Agent of Canine Monocytic Ehrlichiosis. PLoS ONE, v.10, n.9, e0139386, p.1-16, Sep. 2015. Available from: <https:// doi.org/10.1371/journal.pone.0139386>. Accessed: Jan. 15, 2019. doi: 10.1371 /journal.pone. 0139386 .

PAULINO, G. P. et al. Epidemiology of Ehrlichia canis in healthy dogs from the Southeastern region of the state of Rio de Janeiro, Brazil. Preventive Veterinary Medicine, v.159, p.135142, Nov. 2018. Available from: <https://doi.org/10.1016/j. prevetmed.2018.09.012>. Accessed: Aug. 10, 2018. doi: 10.1016/j. prevetmed.2018.09.012.

RAMOS, C. A. N. et al. Comparação de nested PCR com o diagnóstico direto na deteç̧ão de Ehrlichia canis e Anaplasma platys em cães. Revista Brasileira de Parasitologia, v.18, supl. 1, p.58-62, Dec. 2009. Available from: <http://dx.doi.org/10.4322/ rbpv.018e1011>. Accessed: Jan. 02, 2019. doi: 10.4322/ rbpv.018e1011.

RAMOS, R. et al. Molecular survey and genetic characterization of tick-borne pathogens in dogs in metropolitan Recife (north-eastern Brazil). Parasitology Research, v.107, n.5, p.1115-1120, Oct. 2010. Available from: <https://doi.org/10.1007/s00436-010-19797>. Accessed: Feb. 25, 2019. doi: 10.1007/s00436-010-1979-7.

RIBEIRO, M. C. et al. Molecular epidemiology of Anaplasma platys, Ehrlichia canis and Babesia vogeli in stray dogs in Paraná, Brazil. Pesquisa Veterinária Brasileira, v.37, n.2, p.109-136, Feb. 2017. Available from: <http://dx.doi.org/10.1590/s0100736x2017000200006>. Accessed: Oct. 24, 2018. doi: 10.1590/ s0100-736x2017000200006.

RUFINO, C. P. et al. Detection of Ehrlichia canis and Anaplasma platys DNA Using Multiplex PCR. Vector-Borne and Zoonotic Diseases, v.13, n.12, p.846-850, dec. 2013. Available from: $<$ https://doi.org/10.1089/vbz.2013.1303>. Accessed: Jun. 30, 2019. doi: $10.1089 /$ vbz.2013.1303

SILVA, F. C. G. et al. Occurrence of Ehrlichia canis and Anaplasma platys in household dogs from northern Parana. Revista Brasileira de Parasitologia Veterinária, v.21, n.4, OctDec. 2012. Available from: <http://dx.doi.org/10.1590/S198429612012005000009>. Accessed: Oct. 30, 2018. doi: 10.1590/ S1984-29612012005000009.

SILVA, B. C. et al. Molecular detection and characterization of Anaplasma platys in dogsand ticks in Cuba. Ticks and Tick-borne Diseases, v.7, n.5, p.938-944, Jul. 2016. Available from: <https:// doi.org/10.1016/j.ttbdis.2016.04.012>. Accessed: May, 12, 2019. doi: 10.1016/j.ttbdis.2016.04.012.

SOARES, R. et al. Molecular survey of Anaplasma platys and Ehrlichia canis in dogs from Campo Grande, Mato Grosso do Sul, Brazil. Anais da Academia Brasileira de Ciências, v.89, n.1, p.301-306, Jan-Mar. 2017. Available from: <http://dx.doi. org/10.1590/0001-3765201720150556>. Accessed: Feb. 03, 2019. doi: 10.1590/0001-3765201720150556.

VIEIRA, T. F. et al. Tick-borne infections in dogs and horses in the state of Espírito Santo, Southeast Brazil. Veterinary Parasitology, v.249, p.43-48, Jan. 2018. Available from: <https:// doi.org/10.1016/j.vetpar.2017.11.005>. Accessed: Jan. 20, 2019. doi: 10.1016/j.vetpar.2017.11.005.

VLAHAKIS, A. P. et al. Molecular detection and characterization of zoonotic Anaplasma species in domestic dogs in Lusaka, Zambia. Ticks and Tick-borne Diseases, v.9, n.1, p.39-43, Jan. 2018. Available from: <https://doi.org/10.1016/j.ttbdis.2017.10.010>. Accessed: Mar. 05, 2019. doi: 10.1016/j.ttbdis.2017.10.010.

WITTER, R. Prevalência da erliquiose monocítica canina e anaplasmose trombocítica em cães suspeitos de hemoparasitose em Cuiabá, Mato Grosso. Semina: Ciências Agrárias, v.34, n.6, supl.2, p.3811-3822, Oct. 2013. Available from: <https://doi. org/10.5433/1679-0359.2013v34n6Supl2p3811>. Accessed: Dec. 10, 2018. doi: 10.5433/1679-0359.2013v34n6Supl2p3811.

YANG, X. et al. Development of a nested-PCR assay for the rapid detection of Pilidiella granati in pomegranate fruit. Scientific Reports. v.7, n.8, Jan. 2017. Available from: <https://doi. org/10.1038/srep40954>. Accessed: Mar. 02, 2019. doi: 10.1038/ srep40954. 